\title{
Dyggve-Melchior-Clausen Syndrome
}

National Cancer Institute

\section{Source}

National Cancer Institute. Dyggve-Melchior-Clausen Syndrome. NCI Thesaurus. Code C124844.

A rare, autosomal recessive inherited syndrome caused by mutations in the DYM gene. It is characterized by abnormal skeletal development, microcephaly, and intellectual disability. 